\title{
TRANSFORMATION PROCESSES IN CENTRAL ASIA ON THE BACKGROUND OF INTRAREGIONAL CONFLICTS
}

\begin{abstract}
This article explores certain problems within the current processes of regionalization in Central Asia as a means of self-identification of the region in the new conditions. The different starting potential for economic development among the newly independent states has predefined the strategy for forming intergovernmental relations. A special attention is given to the analysis of the political situation in the region after collapse of the Soviet Union in the context of problems concerning disputed territories and questions of the use of water resources of transboundary rivers. Unfair (in the opinion of the countries of Central Asia) division of state borders demarcated during the Soviet era still prevents the regional neighbors from structuring an adequate relations. Territorial conflicts often result in armed clashes. The water-energy resource is another important factor of cooperation in Central Asia and often leads to an open confrontation between the states of the upper reaches of the transboundary rivers and the countries of the lower reaches concerning the use of the hydroelectric potential. The article implements factor analysis and interdisciplinary approach in studying the intraregional conflicts regarding the use of water resources of the transboundary rivers. The author reviews various attempts of intergovernmental collaboration and the causes that stand in the way of these processes. The article reveals the negative role of the border, energy and water conflicts within the regional cooperation. Researching the processes of transformation in Central Asia allowed the author to determine that the political and economic development of the countries progresses unevenly, and forms on the background of objective and subjective factors. The low level of intraregional cooperation outside integrational unions leads to economic and political dependency of each of the countries upon the influential global players.
\end{abstract}

Keywords: Central Asia, transformation, territory, problems of transboundary rivers, regionalization, border conflicts, international organizations, integration, conflict of interests, international relations.

Аннотация: В данной статье рассматриваются проблемы, связанные с процессами регионализации и интеграции в Центральной Азии. Обращается внимание на разные экономические возможности новых независимых государств и их геополитические особенности. Обращается внимание на проблему разрешения спорных территорий государств этого региона и вопросы использования водных ресурсов трансграничных рек. Автор считает, что разделение государственной граниџы во времена Советского Союза было осуществлено недобросовестно, что послужило толчком кобразованию множества территориальных конфликтов. Автор рассматривает различные попытки межправительственного сотрудничества и проблемы в их развитии. Отмечается, что управление водно-энергетическими ресурсами является важным фактором сотрудничества в Центральной Азии. Статья раскрывает негативную роль пограничных, водных и энергетических конфликтов в рамках регионального сотрудничества. Исследование процессов трансформации в Центральной Азии позволило автору определить уровень политического и экономического развития стран, обратить внимание на его неравномерное развитие. Обращается внимание на низкий уровень внутрирегиональной кооперации за пределами интеграционных структур. Ключевые слова: Центральная Азия, трансформачия, территория, проблемы трансграничных рек, районирование, пограничные конфликты, международные организации, интеграция, конфликт интересов, международные связи.

constant topic amongst experts is the problems of regional development of the countries of Central Asia in the context of transformational processes. First and foremost, it is the level of self-identification of the region and its capability for independent economic and political existence after the collapse of the USSR.
Despite the fact that geographically and economically the nations of the Central Asia can compose a single geopolitical region, the level of intergovernmental relations remains in the state of strong dependency upon the intraregional controversies and the role of external actors. Thus, to speak of stable and mutually beneficial 
intraregional connections within the region is out of the question; the economic relations with third parties supersede the regional connectedness. The states of the region are significantly dependent on the export of raw materials and energy sources that results in an economic criterion of regionalization, which forms within the region in a rather problematic manner and causes controversies within the correlation of national interests of the regional players and leads to a political instability of the entire region.

\section{Positions of the countries}

The political and economic situation within the region is being formed in such way that the countries cannot objectively hold stable positions in the world as independent players. As a result, throughout the last 24 years the newly independent states located in the Central Asia are constantly stand before a choice in their economic and political preferences between the key global players such as Russia, China, Europe, and the US. Despite the declared and conducted "open door" policy, in other words a multi-vector policy, the decision making depends on the current situation, specific countries, and the positions of the ruling elites.

The period of establishing of the new post-Soviet countries within the region was developing differently, but even within the first years of independence all of the countries proclaimed the principles of building democratic states, refusing the further development according to planned economy, which was very appealing to the European countries and the United States. The countries of the region have adopted the values, standards and political responsibilities declared by the international organizations (UN, OSCE), as well as democratic states. At the same time, we can note that after so many years of independence none of the countries of Central Asia have built a truly democratic state. On the contrary, we can confirm that these countries are of authoritarian regimes with some external democratic attributes (referendums, presidential and parliament elections, activities of supposedly opposition political parties and social movements). In all actuality, the only countries that have some oppositional power (with certain exceptions) are Kazakhstan and Kyrgyzstan.

Until 2010, the most advances in this regard was Kyrgyzstan, with political parties periodically taking action, the country had an active civil society, and conducted legal, civil and social reforms. A substantial role was played by the opposition, which practically led to two revolutions, and in 2010, not only resulting in change of leadership in the country, but also to the changes in the political structure from a presidential republic to a parliamentary. But as it turned out, the parties and leaders that changed one another have eventually ended up in the same positions of a corrupt leadership, further promoting favoritism and nepotism. This is how Kurmanbek Bakiyev, who has come to power in Kyrgyzstan in 2005 on the wave of the "Tulip Revolution", has given a number of key positions to his relatives. The most controversial was the assignment of his son Maxim Bakiyev the post of the director of the Central Agency for Development, Investment and Innovation, who practically had the authority of a Prime-Minister. Among other factors, this has served as a cause for the April 2010 revolution in Kyrgyzstan and the impeachment of Kurmanbek Bakiyev. In Uzbekistan, the opposition is virtually non-existent; dissidents are subject to persecution and receive lengthy prison sentences. In Tajikistan, there is also no real oppositional force, despite the existence of a multiparty system. Only two parties, the Islamic Renaissance Party and the Communist Party of Tajikistan are de jure considered oppositional, but de facto do not have realistic leverage allowing them to stand their positions and are constantly subject to persecution from the official authorities, especially during the election season. Practically all leaders of the opposition in Turkmenistan are either convicted and are serving a prison sentence, or live in exile overseas.

The republics of Central Asia are very diverse in their political weight and status not only in the world, but also within the region. They hold different positions based on the level of their economic development. Two leaders and "perpetual adversaries" within the region are Kazakhstan and Uzbekistan, which compared to other states, possess large territories and population. Kazakhstan holds a $9^{\text {th }}$ place among the countries with the largest territories in the world. Uzbekistan has the highest number of population within the region of 30.5 million citizens, and holds $42^{\text {nd }}$ place in the world. By their GDP both countries stand far ahead of their regional neighbors. According to the 2013 data of the World Bank the GDP of Kazakhstan is 395 billion USD, Uzbekistan - 156 billion USD, while Turkmenistan is at 73.4 billion USD, Tajikistan at 20.6 billion USD, and Kyrgyzstan at 18.4 billion USD.

Possessing significant deposits of raw minerals and fuel and energy resources allows Kazakhstan and Uzbekistan to dominate and conduct their own internal policy within the region, and even invest (Kazakhstan) into the Tajikistan's and Kyrgyzstan's economies; in other words, they can be called the "locomotives" of the economy in the region.

Since the collapse of the USSR, the republics of Central Asia have gotten their independence without planning for it initially. As a Kazakh historian Asylbek Bisenbaev rightfully notes, the goal was to reform the USSR; to 


\section{Право и политика 4 (184) 2015}

democratize the relations within it, but preserve the unity. The republics viewed the consequences of the failure of the entire USSR system as a break in the economic ties, aggravation in interethnic relations, and influx of the masses of conflict potential [1].

Thus the countries were choosing the path of their future development based on their own domestic economic, resource and intellectual capabilities. Considering the fact that the countries of Central Asia despite their certain peculiarities were an intrinsic part to a once united country, the leadership of the republics understood the importance and the need for regional integration as a functional mechanism for solving border, water, energy, trade, and other conflicts. Any integrational contacts could be useful in the resolution of disputes between the heads of states.

In order to coordinate trade relations and address political issues the countries have come to a decision on bringing together the formerly united republics under the Commonwealth of Independent States (CIS). Despite all the negatives of the CIS that are a constant topic among the experts and politicians the organization continues to carry out its certain intermediary and peacekeeping role. Some of the member states are making effort to not only protect the organization, but to also revamp it; thus the president of Kazakhstan even proposed devising a new development concept for the CIS. In 1992 the countries of Central Asia have joined the Economic Cooperation Organization (ECO) along with Pakistan, Afghanistan and Azerbaijan. The ECO is a regional transnational economic structure that was formed in 1985 by Iran, Pakistan and Turkey, and functioned based on the Treaty of Izmir signed by the three countries on March 12, 1977. At the regional level, in 1993 five nations of the region have signed the protocol on creation of a new common market. In 1994, Kazakhstan, Uzbekistan ans Kyrgyzstan have signed an agreement on the Common Economic Space that would secure the freedom of moving goods, services, capital, workforce, and accord in the customs and currency policies. Although short lived, in 2002 the Organization of Central Asian Cooperation (OCAC) was formed; in 2005 it merged with the Eurasian Economic Community (EurAsEC) that was succeeded by the Eurasian Economic Union (EEU) in 2014, taking in two new member-states from Central Asia. With the exception of the latter, all these organizations did not bring the countries to the expected results due to the limitation of their political and economic resources. The EAEC has just begun to function and it is still too early to speak of any results.

It is worth noting that the collapse of the key integrating elements of the USSR has predefined the economic nature of these organizations at a new market level. The need for a new integration was strengthened by the realization of a complex of common social and environmental problems; the economies of the countries required a serious modernization and their effective solution depended on unification of resources and effort, for which none of the countries individually had the financial or technological capabilities.

\section{Transformational processes}

The political cooperation within the region was forming in an extremely difficult and slow pace. This was due to the fact that the countries were striving to find and revive their ethnic and civilizational identity, attempting to gradually distance themselves from anything that tied them to their Soviet past. From the times of the union the republics retained many unresolved issues. Among them are the historically arbitrary national-territorial division of the republics of Central Asia, which took place in the 1920-1930's and became one of the most painful moments in the historical past of the nations. The issues of delimitation and demarcation of the borders with neighbors were not resolved in any of the republics; it happened much later, and not in all of the countries. The most radical solution of the border problems was introduced by Turkmenistan when they announced a visa requirement for all the neighboring states in 1999. At the bilateral Uzbekistan-Turkmenistan talks on delimitation of shared border in 1999-2000 the former inter-republic border was recognized as intergovernmental. From 2000 to 2002 the bilateral Uzbekistan-Kazakhstan commission on delimitation of borders has also resolved the disputed areas of these nations. As to the UzbekistanKyrgyzstan border, the issue is still ongoing. The two countries have disagreements over 58 parts of the land that range from $500 \mathrm{~m}$ in size, all the way to $20 \mathrm{~km}$ [8]. There is yet to be a demarcation and delimitation of the border between Uzbekistan and Tajikistan. The issues of border control between Kyrgyzstan and Tajikistan are subject to constant struggles, often resulting in armed conflicts as the borderline is only $60 \%$ complete [8]. The current inter-republic borders continue to remain not as much intergovernmental as they are territorial-administrative.

The territorial and transnational conflicts have and still often result in clashes between the populations of the conflicting sides. Moreover, some portions of the border between Uzbekistan and Tajikistan are minefields. Thus, in 1999 the Uzbekistan side in a unilateral manner under the pretense of a threat of crossing of militants from the Tajikistan territory that borders with the part of Afghanistan known to harbor the militants of an extremist 
Islamic movement of Uzbekistan, have set mines on the portions of their border. This led to many human casualties among the population conducting shepherding near the border. Based on the data of the Tajikistan center on the mine issues, between the year 2000 and 2012 there were over 80 casualties and approximately 100 wounded civilians from the mines set by the Uzbekistan [9]. A similar situation can be found at the border between Uzbekistan and Kyrgyzstan, where some parts of the border has also been turned into a minefield. Safety and stability of the entire region directly depends on the economic and environmental state of the main agricultural region of Central Asia - the Fergana Valley [11]. This is precisely where the enclaves and disputed territories are located. At the southern part of Kyrgyzstan in the Batken Region are the Uzbek enclaves of Shohimardon and Sokh, Tajik enclave Vorukh, and in Uzbekistan - the Kyrgyz village of Barak. Today, these territories are the center of constant issues with transportation isolation, conflicts with water distribution and use of agricultural resources.

Thus the interruption of electricity, supply of drinking and irrigation water within the region (including in the Fergana Valley) result in the escalation of social tensions and transnational conflicts in the near-border regions where the disputed water channels and rivers are located [3].

The collapse of the Soviet Union resulted in the differentiation in the level of social and economic development among the newly independent states. The less economically developed and territorially smaller but more densely populated Tajikistan and Kyrgyzstan had significantly different economic priorities compared to the resource-rich Kazakhstan, Uzbekistan and Turkmenistan. As a result, the countries were attempting to structure their political future independently or with the help of their new partners represented by the developed countries, ignoring the interests of their regional neighbors.

Another factor that affects the transformational processes in Central Asia is the unspoken competition between Uzbekistan and Kazakhstan for the regional leadership; at the same time, Uzbekistan so far seems to stand in the second place. This race for the regional leadership is being greatly outweighed by the increasing influence of Kazakhstan as one of the founders and active members of the Customs Union (CU) and the Eurasian Economic Union (EAEU), as well as the integrational initiatives of its president. Due to the emerged political necessity to expand the EAEU and the influence of Russia, who is the principal integrator of the CU and EAEU, Kazakhstan can change their priorities and side with Kyrgyzstan and Tajikistan in the important regional water and energy issue.
Uzbekistan will most likely not be satisfied with the secondary role in the region, as Islam Karimov has repeatedly underlined the independent and special status of his country. It is worth mentioning that in order to strengthen their position in the world the republic is actively cooperating with the European countries and the United States, especially in the military field and the issues of ensuring regional security, which is of great importance due to the neighboring and constantly warring Afghanistan. It is possible that Tashkent would undertake certain actions in order to raise its status within the region. As a fine strategist, Islam Karimov often focuses the attention on the security issues using the regional proximity to Afghanistan and Pakistan, where many of the terrorist organizations are concentrated. For the foreign players it is very important to understand just how the problems of effective management of the borders, regulation of the migrant flow, fight against organized crime, human, drug and arms trafficking will be resolved.

\section{Problems with water usage}

The countries of Central Asia possess a vast energy potential, developed energy infrastructure, and a convenient geopolitical location between Europe and South Asia. An important factor becomes the appropriation of resources, including hydroelectric. Water is the most important geoeconomic and strategic resource for development, and provides the ability to modernize the economy, social sphere, and control the situation in Central Asia. Along with natural gas and oil, water becomes a strategic and political weapon that countries are attempting to utilize.

Due to the arid climate and the practical importance of water for the livelihood of population and agriculture of the region, the transboundary nature of the two large river systems Syr Darya and Amu Darya, located on the territory of Central Asia and Kazakhstan, elevates the need to regulate the water usage for the purpose of irrigation and energy production. One of the causes for disagreements are the difficulties associated with respecting the economic interests in maintaining and using the hydroelectric objects in the zones of formation of the river runoffs, when the main costs for maintaining the regional irrigational systems in working order lies on the shoulders of Tajikistan and Kyrgyzstan, while the biggest consumers of the water resources are Uzbekistan, Kazakhstan and Turkmenistan.

Kyrgyzstan and Tajikistan, although have a lower potential for economic development, possess the bigger part of the regional reserves of fresh water, and their location allows them to regulate the runoffs of the main rivers of 


\section{Право и политика 4 (184) 2015}

Central Asia - Amu Darya and Syr Darya, which provide irrigation of farmland throughout the entire region. But this is namely the cause for the heated intraregional arguments, as the water is in higher demand by the more economically developed Uzbekistan and Kazakhstan. The opinion of experts seems very reasonable on the fact that "the water issue was (and still is $-Z$. D.) the only wildcard in the hands of the poor countries at the conference table with the rich neighbors, and is sometimes used as a method of exerting pressure upon other countries in order to resolve conflicts" [3].

The problem with water usage in Central Asia has always existed, but has reached new levels in the 1990's. The collapse of the functioning system and strict control from the "Center" led to the fact that the water issue has brought further tensions into the regional relations and became one of the factors preventing regional integration.

Not all of the countries are prepared to resolve the water and energy issues with consideration of the interest of other sides. The problems of water and energy supply are viewed by some of them strictly from the perspective of national security and protection of their national interests. The countries were unable to find an "adequate replacement for the "regulating arm" of the Soviet authority" [5]. The strategy for stable development, including water policy, is one of the key and intrinsic parts of the national strategies. But the non-regulatory nature of the rendered decisions and lack of responsibility for noncompliance leave the intergovernmental water and energy problems unresolved. This is caused by the disagreements and disconnection of actions at the regional and national levels between the states that control the water resources, and those that use them. The situation is aggravated by the absence of functional intergovernmental authorities on water and energy management. Despite the regularity of talks and projects of intergovernmental agreements on the issues of water usage, holding regional conferences and summits, the situation remains unchanged. But without devising mutual and collaborative principles on rational usage of the water resources, any stable regional unity is out of the question.

The current agenda is also affected by the questions of rational usage of hydroelectric resources and creation of a unified energy system of the countries of Central Asia. Raising the issues of rational utilization of the transboundary rivers does not only result in new conflicts, but also hinders the development of any possible mutually beneficial relations, which in turn again leads to open confrontation between the heads of states (Uzbekistan and Tajikistan, Uzbekistan and Kyrgyzstan). The cooling of relations between Dushanbe and Tashkent was partially caused by Tajikistan's decision to build the Rogun Dam in 2008.

In September of 2014 Uzbekistan has once again stated their position before UN on the unacceptability of construction of any large hydroelectric power plants with giant dams that can disrupt the natural runoff of the transboundary rivers, without a thorough analysis of all possible consequences. Construction of hydroelectric objects such as Kambarata Hydro Power Plants in Kyrgyzstan (with combined capacity of both plants is 2,260 MW) and Rogun Plant in Tajikistan (with projected capacity of $3.600 \mathrm{MW}$ and a $335 \mathrm{~m}$ dam) would pose a threat to the water, economic and environmental security of Central Asia, and can lead to the increase in the tensions and growth of the conflict potential within the region [6]. The president of Uzbekistan has openly stated that the expansion of the Rogun Dam in Tajikistan can result in a war (in the region). At the same time, during the Soviet era the launch of some of the Vakhsh River plants benefited not only Tajikistan, but also the neighboring republics. The Nuek Dam alone would allow the same Uzbekistan and Turkmenistan to mutually hydrate 7.4 million acres of land. On another hand, using Turkmenistan's rivers (Syr Darya, Panj and Vakhsh) the neighbors are not eager to share their profits, which in the opinion of the riverhead countries violates the 1997 UN Convention on the Law of the Non-Navigational Uses of International Watercourses. By the International Maritime Law, Tajikistan and Kyrgyzstan are entitled to compensation and portion of the profits earned from the usage of the water resources of the republics.

On the issues of usage of the transboundary rivers, Kazakhstan and Uzbekistan situated at the lower reaches of the river, are still in the similar positions. After the talks with his colleague in June 2013, President Nursultan Nazarbayev has stated the need to "ensure the transparency and consideration of the interests of all the countries of the region. We are certain that the cooperation in this life-important area is only possible based on dialogue, strengthening of mutual trust, and without any confrontation. Issues of one nation should not be resolved at the expense of another." [7]. Tajikistan and Kyrgyzstan however, hold the opposite position, and intend to solve their economic problems via their hydroelectric potential. But due to the emerging political necessity to expand the Customs Union and influence from Russia, Kazakhstan may change their priorities.

Russia's integrational position provided the opportunity to smooth out the water and power issues in Central Asia, where the situation with the water resources constantly worsens. By amount of fresh water reserves Kyrgyzstan 
and Tajikistan are only second to Russia. But the glacial reserves have diminished by approximately $25 \%$. The melting of the glaciers has been affected by the factors other than the global warming alone. The countries of the region are still using some archaic farming systems, which exceed the modern global standards of water usage per unit of produce by anywhere from 3 to 10 times. It is hard to argue with Azhdar Kurtov on the subject that "instead of using the current reserves to serve the water needs, remove the "bottlenecks", and reduce the losses caused by unrefined management of the irrigation systems, the region's countries prefer to create conflict atmosphere" [4].

At the same time, we cannot disagree with the experts on the fact that it is namely the integration of the states exporting the natural resources with the countries possessing vast hydroelectric potential that can speed up the development of not only hydroelectricity, but also the region as a whole [2].

One of the main problems in the hydroelectric segment of the countries of Central Asia remains the need for a renewal of its key funds and integration of national fuel and energy complexes of the CIS. This is related to the fact that even geographically the delivery of energy resources does not always align with the state borders. National energy markets are insufficient in order to realize large power projects. The supply of energy resources at the intergovernmental level helps to ensure the energy security of the countries.

The reforms in these countries are primarily directed towards creation of effective energy markets that would attract larger investments. For example, using direct investments (over 16 billion rubles) Russia has completed the construction of the Sangtuda 1 Hydroelectric Power Plant in Tajikistan. The completion of the project has also marked the end of a longstanding regulation if the runoff of the Vakhsh River. The Sangtuda 1 Hydroelectric Power Plant became the fifth step of the Vakhsh cascade of hydroelectric stations, which reduced the seasonal energy deficit by $30 \%$ and provides approximately $50 \%$ of the overall energy production in Tajikistan; and that is another move forward towards resolving a prolonged energy dispute in the region.

Promoting regional cooperation, including investing into the hydroelectric projects, has already benefited not only Tajikistan, but also the neighboring countries, primarily Afghanistan. Back in 2005 the energy authorities of Tajikistan and Afghanistan have signed the memorandum of understanding for supplying $300 \mathrm{MW}$ of Tajik energy to Afghanistan during the spring and summer seasons. Based on the data from the Agency on Statistics under President of the Republic of Tajikistan, the January-October of 2014 export of energy to Afghanistan has superseded the 2013 numbers by almost $40 \%$. Export of roughly 1.8 million $\mathrm{kWh}$ per day continues even while Tajikistan imposes limitations on energy usage for its own citizens. In January of 2015 alone, Tajikistan has exported approximately 55 million $\mathrm{kWh}$ of energy to Afghanistan. The revenue from this export amounted to 2 million USD [10].

Examining the processes of transformation in Central Asia demonstrates that the political and economic development of the countries is tightly linked with resolution of a whole complex of common regional problems. Among them are: irrational usage of water resources of transboundary rivers, inefficient irrigational policies, poor management of energy resources, lack of control over the migrant flow, territorial disputes and delimitation of borders, and the issues of transportation infrastructure.

The regional cooperation develops unevenly, inconsequentially, and is dependent on objective and subjective factors. The entirety of bilateral issues between Uzbekistan and Kyrgyzstan, Uzbekistan and Tajikistan, Kazakhstan and Kyrgyzstan, form within the context of common territorial and energy problems, and conflicts related to water usage.

It is unfortunate that it is necessary to state the low level of intraregional collaboration outside of integrational unions. The strict centralization of power within the countries does not provide the opportunity for mutual projects at a regional level without participation of economically-strong international players.

The most favorable atmosphere for regional cooperation within Central Asia, which will include regional ties and creation of a stable and conflict-free system, is one that is based on the stimulation of intergovernmental relations with consideration of the national interests of all of the states of Central Asia.

\section{Библиография:}

1. Бисенбаев А. Другая Центральная Азия. Электронная библиотека истории Евразии // URL:http:/www.gumer.info/bibliotek_Buks/History/bisenb/01.php (дата обращения: 19.04.2003)

2. Кадырбекова Б.С., Чукубаев Е.С. Регионализм и регионализация Центральной Азии [Текст] // Вестник КазНУ Сер. Международные отношения и международное право. - №1(57). - 2012

3. Калет А. Водные проблемы Центральной Азии // URL:http:/www.relga.ru/Environ/WebObjects/tguwww.woa/wa/Main?tex tid=228\&level1=main\&level2=articles №7(97) (дата обращения: 09.08.2004) 


\section{Право и политика 4 (184) • 2015}

4. Куртов А. Водные ресурсы как причина конфликтов в Центральной Азии// URL: http://svom.info/entry/350-vodnye-resursykak-prichina-konfliktov-v-centralno/ №3 2013 (дата обращения: 02.05.2013)

5. Международные отношения в Центральной Азии: События и документы [Текст] //Под.ред.А.Д.Богатурова. - 2-е изд.,испр.и доп. - М.: «Аспект Пресс», 2014. с.237

6. Обосновано и твердо - против // URL: http://anhor.uz/society/obosnovanno-i-tverdo-mi-protiv (дата обращения: 29.09.2014)

7. Президент Казахстана поддержал позицию Ислама Каримова в вопросе трансграничных peк// URL: http://catoday.org/ centrasia/8921-prezident-kazahstana-podderzhal-poziciyu-islama-karimova-v-voprose-transgranichnyh-rek.html (дата обращения: 14.06.2013)

8. Средняя Азия и проблемы анклавов: «менять нельзя», «резать по живому»? // http://rus.azattyk.org/content/central_asia_border/24878822.html (дата обращения: 22.02.2015)

9. Территориальные переговоры между Таджикистаном и Узбекистаном завершились безрезультатно. URL: http://www. regnum.ru/news/polit/1502293.html (дата обращения: 23.02.2012)

10. Чоршанбиев П. Таджикистан продолжает стабильные поставки электроэнергии в Афганистан // URL: http://news.tj/ru/ news/tadzhikistan-prodolzhaet-stabilnye-postavki-elektroenergii-v-afganistan (дата обращения: 17.02.2015)

11. Ясинский В.А., Мироненков А.П., Сарсембеков Т.Т. Водные ресурсы трансграничных рек в региональном сотрудничестве стран Центральной Азии [Текст]// Алматы, $2010-264$ с. - с. 87

12. А.Ю. Бельянинов Политическая и социально-экономическая роль России в интеграционном процессе на постсоветском пространстве // Политика и Общество. - 2013. - 5. - С. 597-605. DOI: 10.7256/1812-8696.2013.05.8.

13. Бородин Е.А. Республика Кыргызстан и возвращение России в Центральную Азию // Национальная безопасность / nota bene. - 2013. - 4. - C. 613-619. DOI: 10.7256/2073-8560.2013.4.7751.

14. А.Ю. Бельянинов Безопасность России на Евразийском пространстве // Национальная безопасность / nota bene. - 2013. - 2. - C. 318-324. DOI: 10.7256/2073-8560.2013.02.10.

15. Бородин Е.А. Современные политические реалии Центральной Азии: Россия, Китай и Кыргызстан // Политика и Общество. - 2014. - 1. - С. 27-39. DOI: 10.7256/1812-8696.2014.1.9997.

16. Бородин Е.А. Центральная Азия как геостратегический проект, обеспечивающий долгосрочные интересы России // Мировая политика. - 2013. - 3. - C. 1-17. DOI: 10.7256/2409-8671.2013.3.9090. URL: http://www.e-notabene.ru/wi/article_9090.html

\section{References (transliterated):}

1. Bisenbaev A. Drugaya Tsentral'naya Aziya. Elektronnaya biblioteka istorii Evrazii // URL:http://www.gumer.info/bibliotek_Buks/ History/bisenb/01.php (data obrashcheniya: 19.04.2003)

2. Kadyrbekova B.S., Chukubaev E.S. Regionalizm i regionalizatsiya Tsentral'noi Azii [Tekst] // Vestnik KazNU Ser. Mezhdunarodnye otnosheniya i mezhdunarodnoe pravo. - №1(57). - 2012

3. Kalet A. Vodnye problemy Tsentral'noi Azii // URL:http://www.relga.ru/Environ/WebObjects/tguwww.woa/wa/Main?textid=2 28\&level1=main\&level2=articles №7(97) (data obrashcheniya: 09.08.2004)

4. Kurtov A. Vodnye resursy kak prichina konfliktov v Tsentral'noi Azii// URL: http://svom.info/entry/350-vodnye-resursy-kakprichina-konfliktov-v-centralno/ №3 2013 (data obrashcheniya: 02.05.2013)

5. Chorshanbiev P. Tadzhikistan prodolzhaet stabil'nye postavki elektroenergii v Afganistan // URL: http://news.tj/ru/news/ tadzhikistan-prodolzhaet-stabilnye-postavki-elektroenergii-v-afganistan (data obrashcheniya: 17.02.2015)

6. Yasinskii V.A., Mironenkov A.P., Sarsembekov T.T. Vodnye resursy transgranichnykh rek v regional'nom sotrudnichestve stran Tsentral'noi Azii [Tekst]// Almaty, $2010-264$ s. - s. 87

7. A.Yu. Bel'yaninov Politicheskaya i sotsial'no-ekonomicheskaya rol' Rossii v integratsionnom protsesse na postsovetskom prostranstve // Politika i Obshchestvo. - 2013. - 5. - C. 597-605. DOI: 10.7256/1812-8696.2013.05.8.

8. Borodin E.A. Respublika Kyrgyzstan i vozvrashchenie Rossii v Tsentral'nuyu Aziyu // Natsional'naya bezopasnost' / nota bene. - 2013. - 4. - C. 613-619. DOI: 10.7256/2073-8560.2013.4.7751.

9. A.Yu. Bel'yaninov Bezopasnost' Rossii na Evraziiskom prostranstve // Natsional'naya bezopasnost' / nota bene. - 2013. - 2. - C. 318-324. DOI: 10.7256/2073-8560.2013.02.10.

10. Borodin E.A. Sovremennye politicheskie realii Tsentral'noi Azii: Rossiya, Kitai i Kyrgyzstan // Politika i Obshchestvo. - 2014. - 1. - C. 27-39. DOI: 10.7256/1812-8696.2014.1.9997.

11. Borodin E.A. Tsentral'naya Aziya kak geostrategicheskii proekt, obespechivayushchii dolgosrochnye interesy Rossii // Mirovaya politika. - 2013. - 3. - C. 1-17. DOI: 10.7256/2409-8671.2013.3.9090. URL: http://www.e-notabene.ru/wi/article_9090.html 